International Journal of Agriculture, Environment and Bioresearch

Vol. 5, No. 05; 2020

ISSN: $2456-8643$

\title{
STUDY ON INTRA-AFRICAN TRADE IN CONGO TIMBER
}

\author{
NGOYA-KESSY Alain Marius ${ }^{1,2,3}$, AYESSA LECKOUNDZOU ${ }^{1,3,4}$, EWOSSAKA Arsène $^{1,2,3}$, BITSI Gervais $^{5}$ \\ ${ }^{1}$ University Marien NGOUABI (UMNG) \\ ${ }^{2}$ Study firm on Traceability and Forest Economy \\ ${ }^{3}$ Laboratory of Geomantics and Applied Tropical Ecology \\ ${ }^{4}$ National Forest Research Institute (IRF) \\ ${ }^{5}$ Export Forest Products Control Service
}

https://doi.org/10.35410/IJAEB.2020.5549

\begin{abstract}
This work aims to fill the information gap on formal intra-African trade in timber products. It could thus be useful at different levels: national institutions and companies, international institutions, universities, research, companies, chamber of commerce. Its objective is to generate data in order to fill the information and knowledge gap on intra-African trade in timber and derived products, in order to guide priority actions to formulate policies and strategies to encourage trade in products. timber between countries with forest and countries without forest resources in Africa.

Considering the period from 2009 to 2017, timber exports remain marginal. They are below 3\%, compared to all exports of wood products and Congo. In real terms (in volume), Africa is in 4th place of exports of forest products from Congo, far behind South East Asia, the European Union and the Middle East. In terms of value, it is in 5th place, still very far behind South East Asia, the European Union, the Middle East and North America.
\end{abstract}

Keywords: Trade, Timber, Products, Forestry And Export.

\section{INTRODUCTION}

The present work, the timber trade between African countries concerns wood goods or products such as logs, wet and dried sawnwood, peeled and sliced veneers, plywood and wood chips or chips. Only the registered movements of its products from Congo to third African countries will be taken into account, including the traffic from customs warehouses at the Port Autonome de Pointe-Noire.

So the flow here concerns the exports of these products which decrease the stock of these material resources in Congo and increase, the importation of this stock in another African country entering. We will not discuss the informal cross-border trade in these products, despite the importance of these flows from Cameroon to Congo and from Congo to the DRC, we will however say a few words in order to attract the attention of decision-makers, because Increasingly large quantities of illegally harvested timber are seized by the Congolese Forest Administration. This year, the Congolese Forest Administration seized 14 parcels of sawn timber containing $30 \mathrm{~m} 3$ from Cameroon (IGEF). In our opinion, these informal flows are more 
important than formal flows, and should attract the attention of COMIFAC and the AfDB ... Likewise, it should be noted that significant volumes of NTFPs of plant origin circulate and are the object of significant intra-African trade.

Foreign trade statistics are based on data contained in import and export declarations, which were previously used for customs clearance. Regarding wood products, in Congo there is an upstream technical service responsible for this collection. This is the Forest Products Export Control Service in the acronym SCPFE which gives discharge through an Export Verification Certificate (AVE) for any wooden product exported from Congo. This service is in charge of the production of timber statistics for export to Congo. For our part, we will extract from the SCPFE directories the data relating to African flows, and transform this primary data in the form of tables and graphs for exports to African countries; this to then facilitate their operations for economic, commercial and other analysis needs.

The main objective of this study is to generate data in order to fill the information and knowledge gap on intra-African trade in timber and derived products, in order to guide priority actions to formulate policies and strategies to encourage trade in wood products between forestendowed and forest-deprived countries in Africa.

The specific objectives of the study are:

1. Gather data on intra-African trade in timber and timber products exported by Congo;

2. Analyze intra-African timber trade data by product categories in terms of importance, flow values and destinations (importing countries in Africa);

3. Identify the bottlenecks, and any factors or challenges to boost intra-African timber trade from Congo;

This study focuses only on one aspect of trade: exports of 4 or 5 wood or wood-derived products over the period from 2009 to 2017. The study should demonstrate the importance of intraAfrican trade in wood and timber. " extend to wood products exported to other African countries, sub-regions of East, Central, North, West and South Africa. Data on the export flows of logs, sawnwood, veneer, plywood and chips between Congo and other African countries are therefore the results of this study. We ran out of time to collect and analyze commercial information on the actual selling prices of these products in the African market, despite our insistence. Usually this information is closed. From experience, we know that these prices are on average $30 \%$ higher than the FOB or FOT prices used for taxation. Research should be done towards importing countries, customs services and customers to identify this problem because the tax shares are considerable.

\section{METHODOLOGY}

The service provided is broad and uses standard methods of analysis of exports of wood products between the countries studied and the five African sub-regions. Trade data (2009 - 2017) on timber comes from variable sources and databases, including national statistics from the ministries in charge of forestry (SCPFE 3017), finance, customs, commerce, chambers of commerce and port authorities. These documents were consulted just to cross-check information. We also contacted resource persons by telephone. 
The methodology adopted for carrying out this study can be broken down into six (6) stages, namely:

(i) Documentary research and identification / exploitation of official SCPFE databases and databases since these data are reliable and trustworthy;

(ii) Collection of data from the SCPFE of the Administrations concerned, in particular the Forestry Administration for verification, monitoring of formatting and processing on Microsoft Excel;

(iii) Statistical analysis of the data collected and estimates of the values according to the prices used FOB or FOT;

(iv) Production of statistical and graphical tables and analysis of the results;

(v) Cross-checking and production of statistics compiled in this report.

\section{CHAPTER 3: STUDY RESULTS}

3.1. Data on intra-African trade in timber exported by Congo to Africa and their analysis by product categories in terms of importance, flow in volume and in value from 2009 to 2017 


\section{At. In volume}

\begin{tabular}{|c|c|c|c|c|c|c|c|c|c|c|}
\hline \multirow{3}{*}{ Libellé des produits } & \multicolumn{9}{|c|}{ (En volume : $m^{3}$ ) } & \multirow{3}{*}{ TOTAL } \\
\hline & \multicolumn{9}{|c|}{ Période : Année 2009 à 2017} & \\
\hline & 2009 & 2010 & 2011 & 2012 & 2013 & 2014 & 2015 & 2016 & 2017 & \\
\hline COPEAUX D'EUCALYPTUS & - & 25100,14 & 117382,24 & 39012,73 & - & - & - & - & - & 181495,11 \\
\hline SCIAGES HUMIDES & 5636,94 & 5607,68 & 5706,10 & 6532,24 & 7439,63 & 6392,60 & 5125,62 & 3773,79 & 2455,60 & 48670,19 \\
\hline SCIAGES SECHES & 459,32 & 986,09 & 1105,26 & 1431,67 & 2204,44 & 2456,98 & 3947,94 & 2364,17 & 1730,86 & 16686,72 \\
\hline PLACAGES DEROULES & 211,70 & - & 2112,05 & 1479,68 & 1321,29 & - & 158,65 & 260,81 & 428,40 & 5972,59 \\
\hline GRUMES & 347,88 & 253,52 & 552,42 & 349,67 & 182,13 & 974,42 & 566,81 & 58,31 & 3446,11 & 6731,27 \\
\hline RONDINS DE PLANTATIONS & 1162,28 & - & 32,55 & - & - & - & - & 148,00 & - & 1342,83 \\
\hline CONTRE PLAQUES & 68,44 & - & 20,13 & 56,73 & 19,77 & 24,03 & 24,40 & - & - & 249,96 \\
\hline PRODUITS FINIS & 65,94 & 45,86 & 52,04 & 54,14 & 5,67 & 26,30 & - & - & - & 213,49 \\
\hline TOTAL & 7952,48 & 31993,28 & 126962,79 & 48916,86 & $\begin{array}{r}11 \\
172,93\end{array}$ & 9874,33 & 9823,43 & 6605,08 & 8060,96 & 261413,05 \\
\hline
\end{tabular}

TOTAL 7,952.48 31,993.28 126,962.79 48,916.86 11172.93 9,874.33 9,823.43 6,605.08 8,060.96 261,413.05

Source: Statistics, SCPFE

Exports of forest products from the Congo to other African countries consist mainly of processed products (wet and dried sawnwood).

There are also exports of peeled veneers, eucalyptus logs, eucalyptus chips or chips and finished products (which consist of wood floors, moldings, furniture items, doors and windows, etc.) .

A look at the exports of forest products from Congo, over the period 2009 to 2017, shows an appearance of eucalyptus chips or chips between 2010 and 2012. These exports recorded a peak in 2011. This is due to the presence of chips or eucalyptus chips.

Since 2013, eucalyptus chips or chips no longer exist in the basket of forest products exported by Congo.

Graph 2: Distribution of timber exported by Congo to other African countries, all products combined, by year, from 2009 to 2017; (in volume: $\mathrm{m} 3$ )

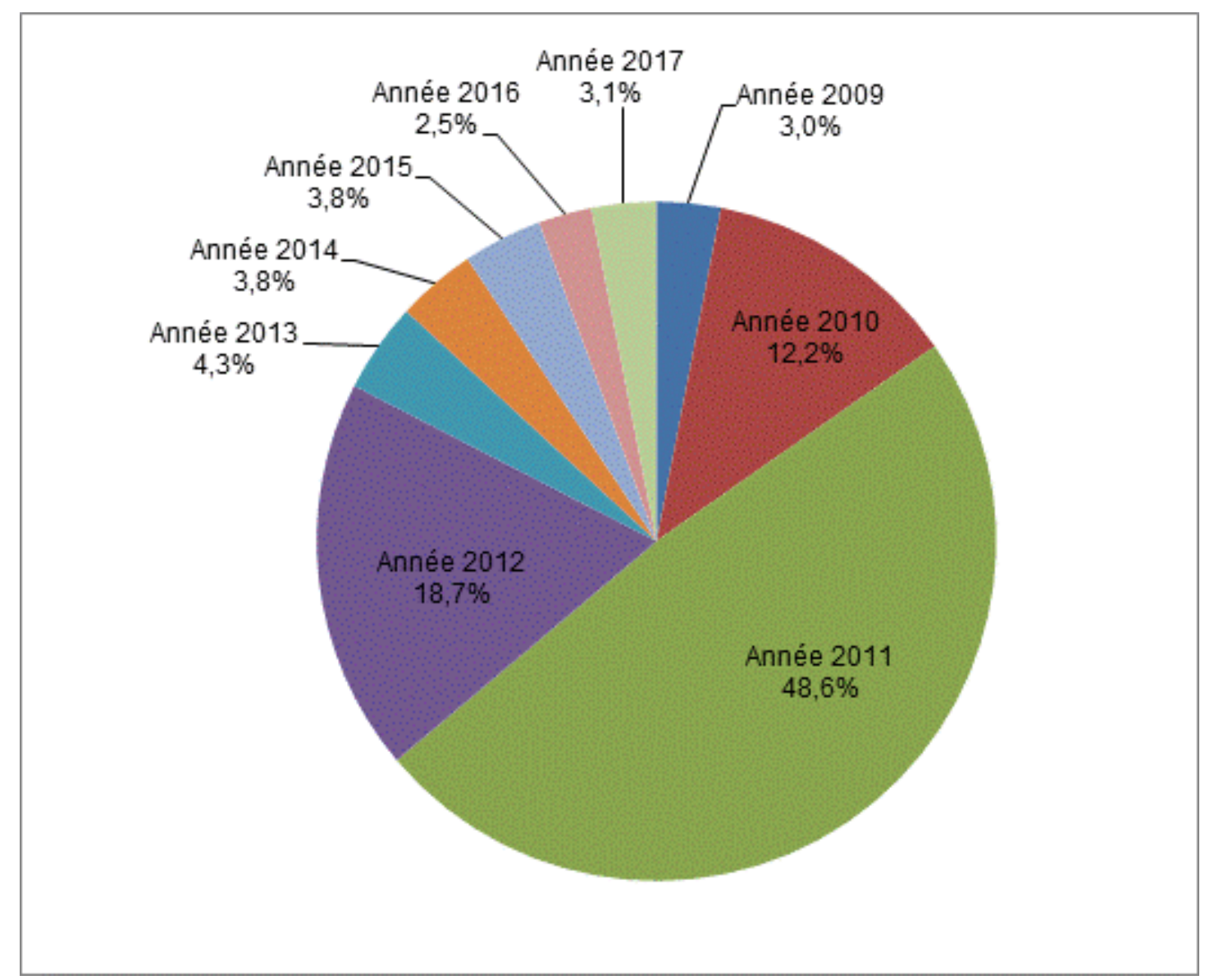


Figure 4: Distribution of timber exports from Congo to other African countries, by product from 2009 to 2017; in volume

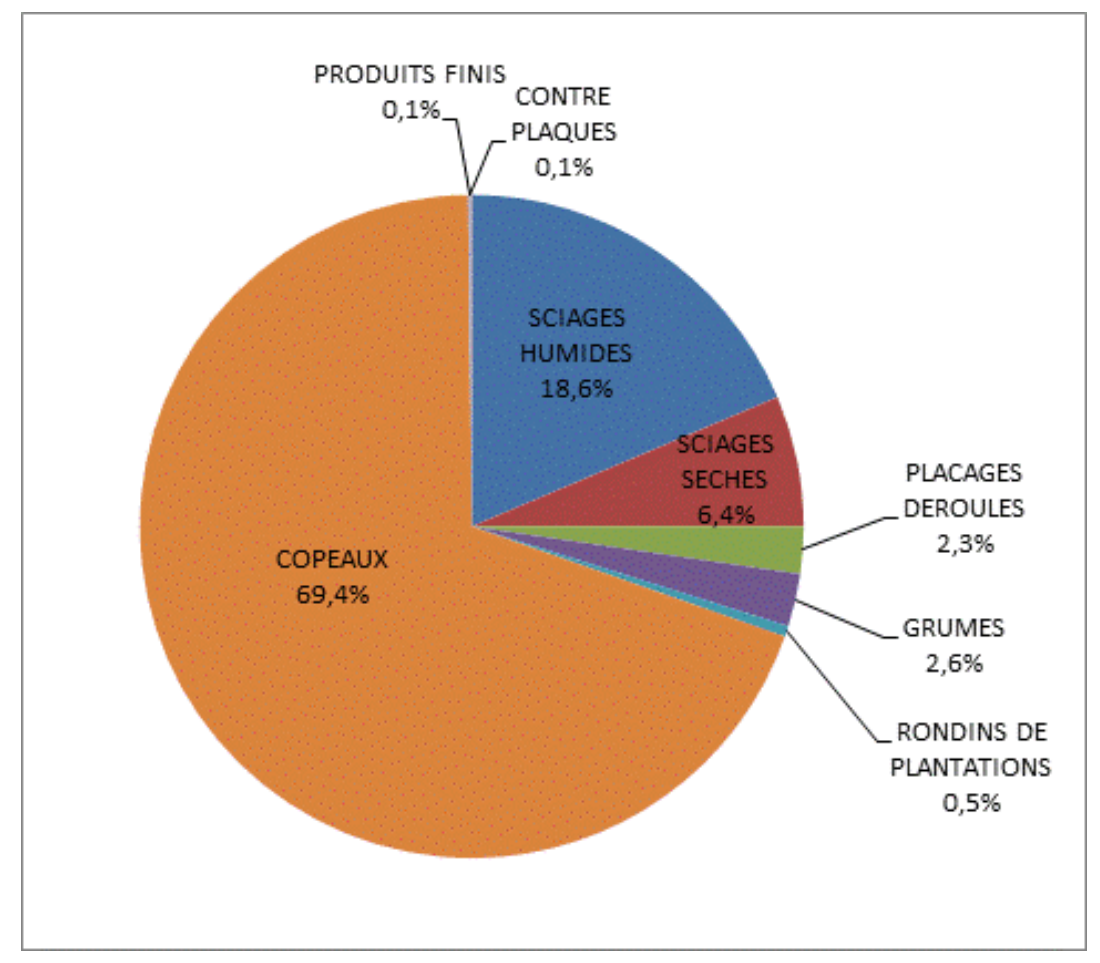

In real terms, over the period, woodchip exports made up more than $2 / 3$ of forest product exports to other African countries. Eucalyptus chips or chips led the annual average upwards, to $29,045.89 \mathrm{~m} 3$; while the minimum value of these exports was recorded in 2016, at 6,605.08 m3. These exports have a normal trend, following the peak of eucalyptus chips in 2012 .

Notwithstanding the exports of eucalyptus chips, the annual average of exports of forest products from Congo to other African countries would be $8,879.77 \mathrm{~m} 3$, and also its low standard deviation and below the average, that is to say 1,469 . This distribution is concentrated. This is so, his GINI index will show it.

We can affirm, given the structure of the Congolese forest industry, held by foreign capital (Asian and European), which favors Asian and European destinations, exports of forest products to other African countries are very low and dominated. by sawn timber.

b. Value

The exports of forest products from Congo to other African countries, in value, have recorded a more or less normal trend, with a more or less marked increase in wet sawnwood in 2009.

During this period, exports for the year 2014, in value, registered a significant decline.

Graph 7: Distribution of timber exports from Congo to other African countries, between 2009 and 2017; in volume

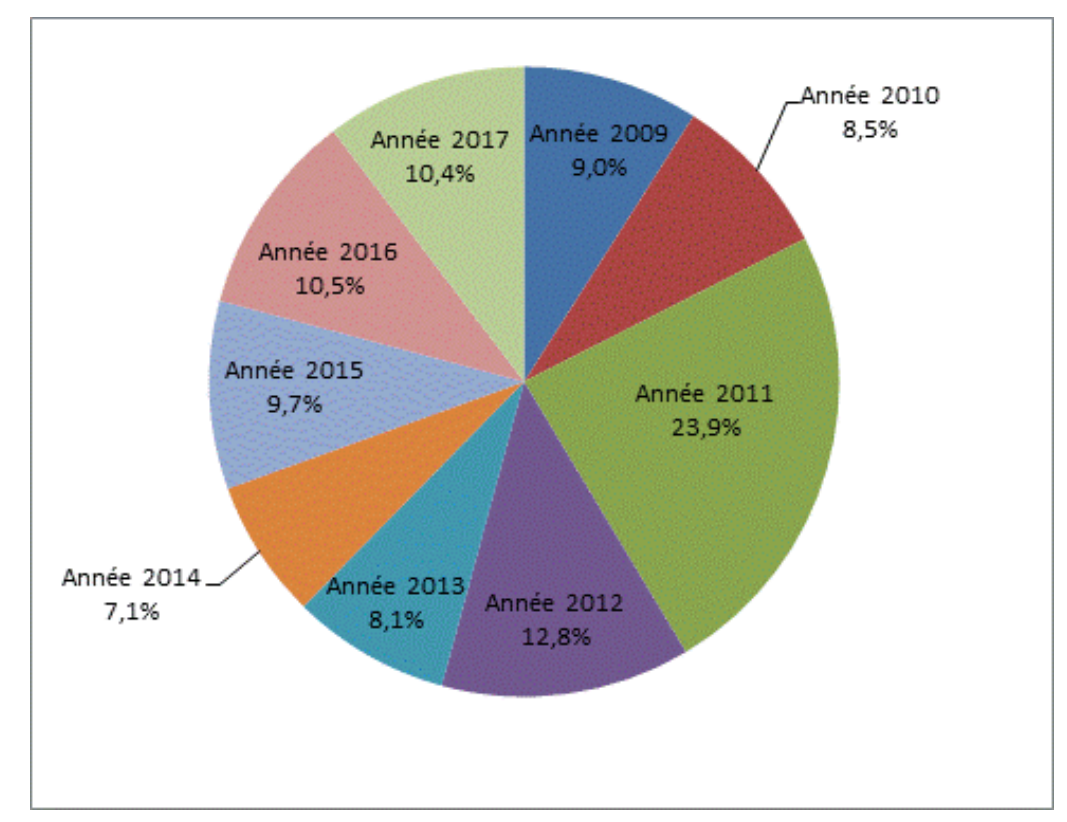

Graph 6: Congo's timber exports to other African countries, by product and year, from 2009 to 2017; in FCFA value.

The presence of eucalyptus chips or chips between 2010 and 2012, allowed distribution to have roughly the same trend as in volume, with a 2011 peak.

After having occupied the first place in terms of export, in volume, with more than $69 \%$ of export share, the eucalyptus chips downgraded by one point, in value, to be in second position, with more a quarter of exports. 


\section{International Journal of Agriculture, Environment and Bioresearch}

Vol. 5, No. 05; 2020

ISSN: 2456-8643

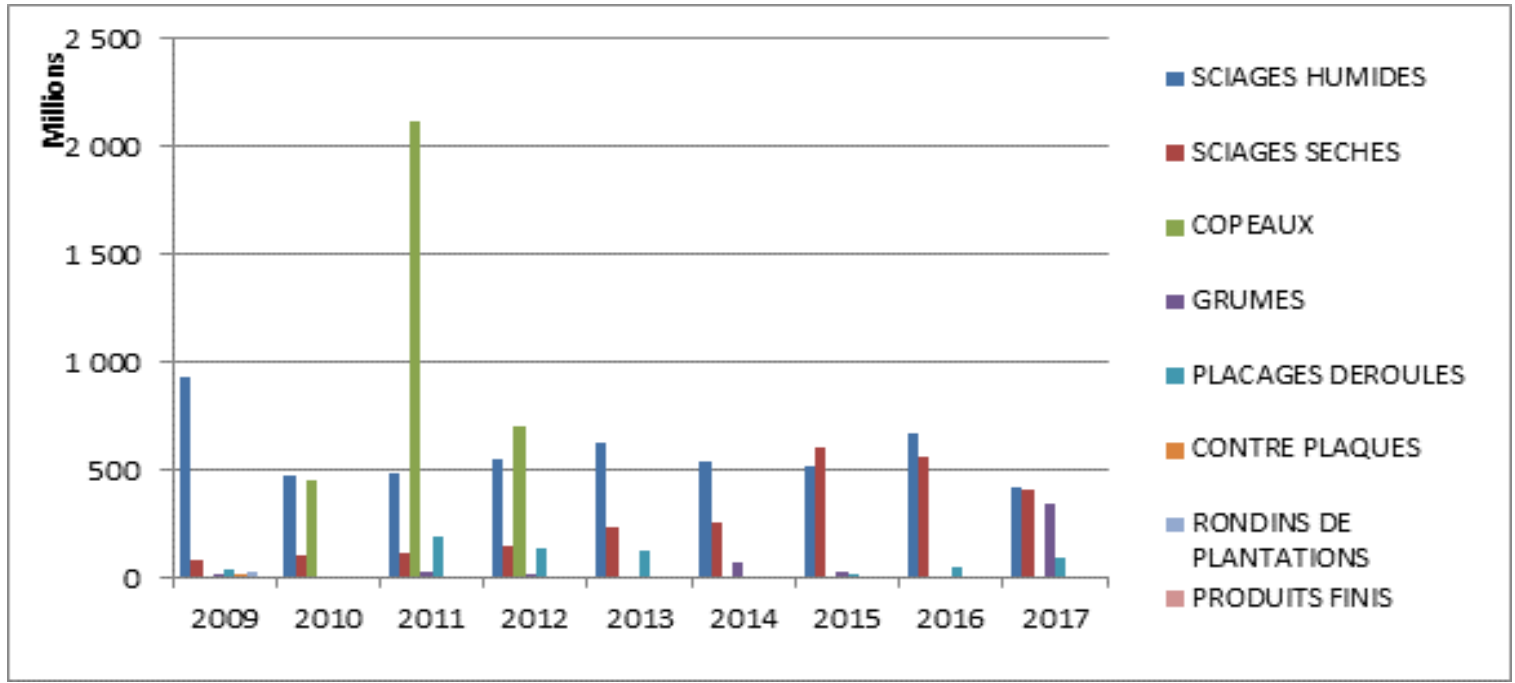

Graph 8: Distribution of timber exports from Congo to other African countries, by product from 2009 to 2017; in CFA F value

The annual average of forest products exports is pulled up because of eucalyptus chips, to $1,369,702,758$ FCFA.

The analysis of the statistical parameters of the distribution, in value, presents the characteristics as in volume.

DATA ON INTRA AFRICAN TRADE IN TIMBER EXPORTED BY CONGO TO AFRICA AND THEIR ANALYSIS BY PRODUCT CATEGORIES IN TERMS OF IMPORTANCE, FLOWS IN VOLUME, IN VALUES, DESTINATIONS BY COUNTRY, FROM 2009 TO 2017

ANALYSIS OF EXPORTS TO AFRICA OF PROCESSED FOREST PRODUCTS FROM CONGO OVER THE PERIOD 2009 - 2017

At. WET SAWNS; (In volume)

Instead of a detailed analysis by year from 2009 to 2017, we offer here a global analysis, over the study period.

In general, exports of forest products from Congo to African countries remain very marginal. For an average annual volume of over one million $\mathrm{m} 3$ exported by Congo, the country exported to other African countries on average less than $4 \%$ of forest products (average volume 29,045.89 $\mathrm{m} 3)$.

These exports are mainly in the form of processed products (wet and dried sawnwood, peeled veneers and eucalyptus chips or chips). There is also a significant amount of raw products (eucalyptus logs and $\log s$ ). 
The main destination is North Africa with Morocco, Tunisia, Algeria and Egypt; then Senegal, Mauritius, Seychelles, South Africa and Reunion Island.

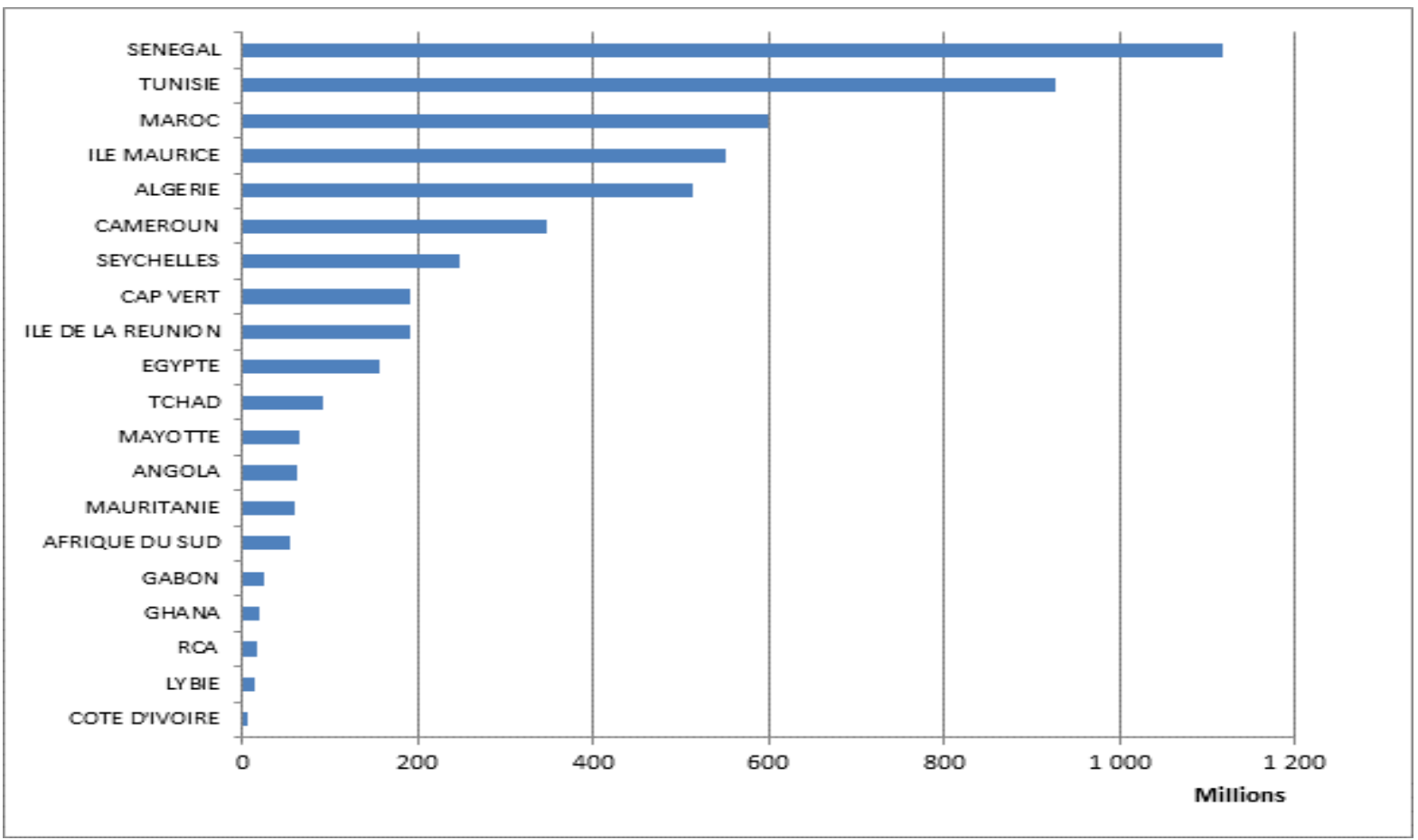

Graph 10: Destinations of wet sawnwood exports from Congo to other African countries, from 2009 to 2017; (in FCFA value)

Logs exported to those countries which do not have tropical sawmills are in reality imports for re-export of logs to the EU or Asia, they are certainly intermediaries.

However, there are significant quantities of forest products from Congo exported to countries in the Sub-Region (Cameroon, Gabon, Angola and DR Congo).

Logs imported by forest countries such as Cameroon can signal an installed (and operational) industrial overcapacity greater than the allowable cut. The factories are running out of logs. It would then be interesting to analyze the volumes of logs not exported at the end of the year (disputes, abandonment, etc.) at the port of Douala. These logs do not make the return trip to the countries of production, they are certainly processed in Cameroon. The Cameroon study should help us understand this situation, as it can threaten sustainability. Industrial overcapacity puts pressure, for example, on community forests and loggers located at the same time in several countries of the Congo Basin.

As for the exports of forest products from Congo to Cameroon, over the period 2010 to 2017, they amounted to $5,109.91 \mathrm{~m} 3$, and in the form of logs, wet and dried sawnwood, and finished 
products, by several forest companies. from North Congo (Mokabi SA, Likouala Timber, SEFYD, SIFCO and IFO). It should be noted that Rougier SA, owner of the Mokabi company, is based in Cameroon, Congo and Gabon.

The exports of forest products from the Congo to Angola and DR Congo were made in the form of Eucalyptus poles, those to Gabon in the form of plywood.

In 2011, there was a negligible quantity of wet sawnwood exported by the COFIBOIS company, located in Pointe-Noire, in the southern part of the country, to Cameroon. However, in 2009 there was an absence of exports to this country.

The analysis in value, of the intra-African trade flow of Congolese timber, shows slightly the same trends as in volume, that is to say a predominance of processed timber products compared to raw products for the same destinations.

During the period, the share of eucalyptus chips or chips which were, in volume of $69.4 \%$, increased from $26.5 \%$ and for wet and dried sawnwood, in volume, respectively from $18.6 \%$ and $6.4 \%$ to $42.5 \%$ and $20.4 \%$. This represents a reduction for eucalyptus chips or chips and an increase for sawnwood. This is due to the relatively low prices for chips and sawnwood (wet and dried).

The share, in value, of forest products from Congo exported to other African countries in total timber exports is very low; or $0.011 \%$.

\section{In value In volume}

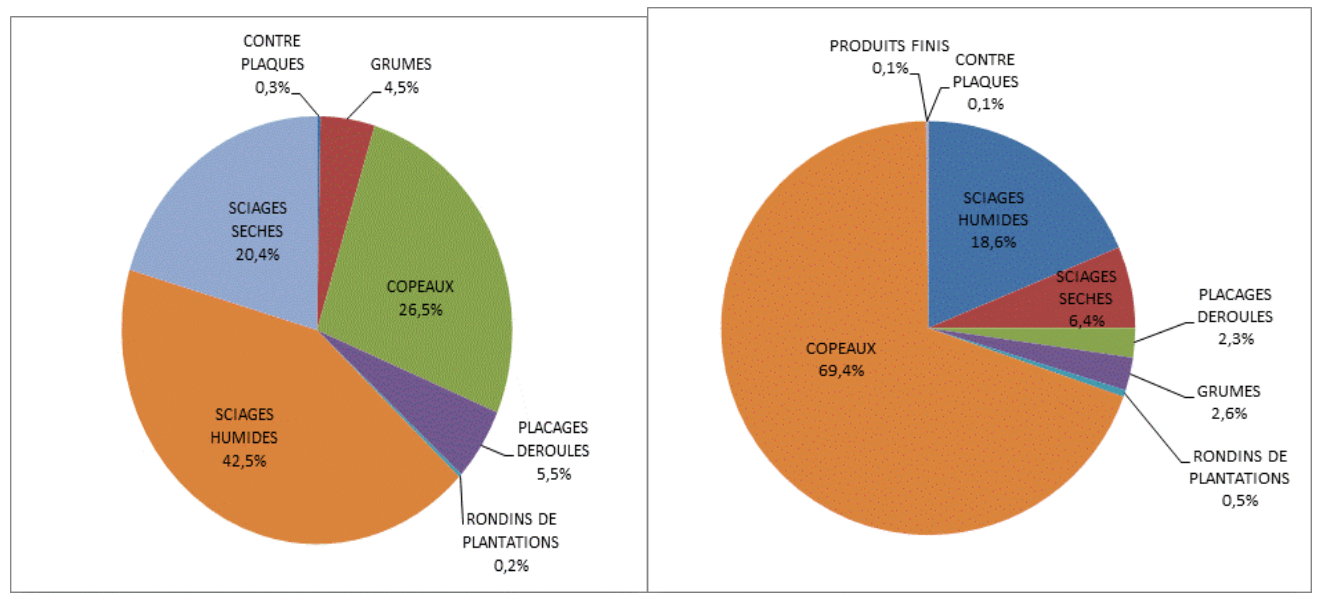

Graph 11: Shares of exports of forest products from Congo to other African countries, from 2009 to 2017; (in volume and in FCFA value)

BOTTLENECKS, FACTORS OR CHALLENGES TO BOOST INTRA AFRICAN TIMBER TRADE FROM CONGO 
Intra African timber trade is faced with:

The narrow African market. Most of the African population has low income, thus having low purchasing power. It is unable to purchase finished or semi-finished wood processing products (moldings, parquet floors, doors and windows, fine furniture and kitchens). Only a small elite in big cities can afford such so-called "luxury" products. The creation and / or the development of a middle class is an economic necessity to boost this trade;

The increase in the range of processed products, from 5 to 15 , for example, as in the EU and Asia;

The popularization of promotional species falsely called "secondary species" to compensate for expensive noble species and thus reduce the pressure on their production. Species such as sapelli and Sipo are in a situation of skimming and their durability is threatened due to the difficult reproduction of meliaceae;

The re-education of African factory and final consumers, so that they do not reproduce the consumer clichés of Europeans who always demand first-choice exotic woods clear of all structural defects and anomalies. This consumption habit is unfavorable to the sustainable management of tropical forests;

The absence or lack of means of communication. Indeed, there are very few lines of communication between African countries, even those that border on the border. This considerably reduces trade between them, especially in Central Africa. Although efforts are being made with the construction of the Congo-Cameroon, Cameroon-Nigeria road. This studies showed that the countries to which the Congo exports have seaports. There is one trade per port to develop and another no road to be created;

The costs of road transport and charter by the Port of Pointe -Noire are not very competitive compared to the port of Douala which in addition offers more destinations;

The stoppage of traffic on the Congo Ocean CFCO Railway for 3 years;

The very high country risk due to political and other conflicts;

The issue of the FCFA which does not promote the development of intra-African trade would only be between West and Central Africa. This issue deserves special attention from the ADB.

To boost intra-African timber trade, African states, in their construction sites: BTP, should favor the consumption of local products like the United Kingdom and Brazil during the construction sites of the Olympic Games in these countries. Instead of importing low quality waste wood products from China;

Train African architects and designers in the use of tropical solid wood in all their projects;

The United Kingdom has favored the use of certified wood during the London Olympic Games construction sites and Brazil has privileged the consumption of domestic wood during the Rio de Janeiro Olympic Games construction sites and the construction of the World Cup stadiums. 
With the creation of economic zones, African timber-producing states should promote the establishment and development of further timber processing industries, in order to relocate sharp industries from the north to the south. This is the option taken by Gabon.

\section{CONCLUSION}

The study on intra-African timber trade between Congo, a COMIFAC country and the others, showed that exports of timber forest products from Congo to African countries (African market, including North Africa) mainly in the form of processed products: wet and dried sawnwood. A total of 27 countries are concerned, representing all sub-regions and mainly countries with a seafront and a port.

Considering the period from 2009 to 2017, these exports remain marginal. They are below 3\%, compared to all exports of wood products and Congo.

In real terms (by volume), Africa ranks 4th in the export of forest products from the Congo, far behind South East Asia, the European Union and the Middle East.

In terms of value, it is in 5th place, still very far behind South East Asia, the European Union, the Middle East and North America.

It should be noted that exports of forest products from the Congo to South East Asia are mainly in the form of raw products in the form of logs.

The marked increase in exports of forest products from Congo to other African countries was due to the emergence of exports of eucalyptus chips or crisps, especially to North African countries (Morocco).

Exports of forest products to countries bordering Congo are almost non-existent. These countries have almost the same economic structure (producer and exporter of wood forest products). There are some imports of logs and wet sawnwood by Cameroon.

The development of road and port infrastructure will promote intra-African timber trade as already evidenced by timber exports from eastern DRC to countries in East and South Africa (Uganda, Rwanda, Kenya , South Sudan ...). Trade facilitation efforts are being made in the Great Lakes region, jointly with the establishment of Economic Zones, and may also play in favor of regional and intra-regional trade.

\section{REFERENCE}

1. DSPAR 2012, Country Strategy Paper Focused on Results Republic of Congo. African Development Bank African Development Fund. Country Operations Department. Center Region. $42 \mathrm{p}$

2. DSRP -2010, Poverty Reduction Strategy Paper 175p Ministry of Planning and Regional Development. Republic of Congo

3. ITTO 2017, Annual Review and Assessment of the World Timber Situation. 2200 pages 
4. Fays Richard. Forests... Woods... Sainte Ode. Belgium. 2008.1022p

5. CBFP 2007, The forests of the Congo Basin. "State of the forests. 256p

6. PFBC 2009, The forests of the Congo Basin. "State of the forests 2008 ".. 425p

7. CBFP 2012, The forests of the Congo Basin. "State of the forests 2010 “.. 274p

8. PFBC 2014, The forests of the Congo Basin. "State of the forests 2013“.. 325p

9. Malaysian Wood, timeless linving. Malaysian Timber Council, 2007, 196p

10. Mémento du forestier1989, 3rd edition, French Cooperation. 1265p

11. Mémento du Forestier Tropical 2015, "Editions Quae“.. 1203p

12. ITTO 2016, Project PD 700/13 Rev.2 (1): Development of Trade in Tropical Timber and Derivatives, and their Industrial Valorization in an Intra-African Framework - Phase 1. Final Workshop Communiqué. Abidjan. Ivory Coast.

13. National Report on Human Development 2010; Human development, poverty and climate change in the Republic of Congo. 2011.93p

14. ECCAS, 2017, Annual Statistics Reports 2000p

15. SCPFE2009, Export of forest products from Congo, Statistical report. Ministry of Sustainable Development, Forestry Economy and the Environment. Republic of Congo. 161p

16. SCPFE2010, Export of forest products from Congo, Statistical report. Ministry of Sustainable Development, Forestry Economy and the Environment. Republic of Congo. 145p

17. SCPFE 2011, Export of forest products from Congo, Statistical report. Ministry of Sustainable Development, Forestry Economy and the Environment. Republic of Congo. 163p

18. SCPFE 2012, Export of forest products from Congo, Statistical report. Ministry of Sustainable Development, Forestry Economy and the Environment. Republic of Congo. 162p

19. SCPFE 2013, Exports of forest products from Congo, Statistical report. Ministry of Sustainable Development, Forest Economy and Environment. Republic of Congo.148p

20. SCPFE 2014, Export of forest products from Congo, Year 2014. Statistical report. Ministry of Sustainable Development, and Forest Economy. Republic of Congo. 153p

21. SCPFE, Export of forest products from Congo, Year 2015. Statistical report. Ministry of Sustainable Development, Forest Economy. Republican 